\title{
The Implications of Theory of Planned Behavior (TPB) on The Student Online Business Intention
}

\author{
Elida F. S. Simanjorang, Yuniman Zebua, Bayu Eko Broto, Meisa Fitri Nasution, Ronal Watrianthos
}

\begin{abstract}
Decision of running business is the result of interaction of several factors, namely the character of a person's personality and environmental influences. A family relationships, friends, relatives, educational environment, social rules in society and religious that can influence one's intentions running a business. Theory of Planned Behavior explains that the intention of doing online business among students is influenced by some variable such as attitudes, subjective norms, and perceive behavioral control. Furthermore, these three variables are influenced by several backgrounds which influence it, such as social, personal / individual background, and information. A number of research results show that the intention of doing online business for each students can vary depending on their social environment, age, gender, level of education, science, level of income, belief/ religion, or the influence of exposure to information which affects their experience, besides the influence of personality and the personal intellectuality of the student. These results of research show that the Theory of Planned Behavior have implications in explaining the phenomenon of intention to run online business among students.
\end{abstract}

Index Terms- Theory of Planned Behavior, Online Business Intention, The Student Online Business

\section{INTRODUCTION}

One of the problems in development in Indonesia is the problem of unemployment. Data from the Indonesian Central Bureau of Statistics (BPS) showed that the unemployment rate in Indonesia is still relatively high. In February 2012, the proportion of unemployed who had the university's final education level was $7.1 \%$ of Indonesia's total unemployment. This portion increased to $8.7 \%$ in February 2017. In addition, the unemployment rate of diploma / academy graduates also showed an increasing proportion. In February 2012, there were 3.3\% unemployment contributed by diploma / academy education and increased to 3.6\% in February 2017. Meanwhile, the proportion of unemployed general high school graduates reflecting unskilled workers showed a declining trend of $26.3 \%$ in February 2012 to $22.2 \%$ in February 2017.

Based on the data form "BPS" above it is known that unemployment is dominated by unemployed university graduates as much as $8.70 \%$. The amount is greater than unemployment from diploma/ academy graduates as much as $3.6 \%$ and unemployment from no / not completed elementary school is $7.8 \%$. This indicates that college graduates become more job seekers than job creators (Azwar, 2009, in Amir, 2017)[1]

Ideally, becoming an entrepreneur is one solution to create jobs and minimize unemployment. The development of entrepreneurship in Indonesia is still limited, this is stated in a publication from Bank Ind ponesia (BI) in November 2014. This publication was stated that these limitations are based on three things, namely the entrepreneurial population, entrepreneurial health and rank in the Group of Twenty (G20) countries. The numbers of entrepreneurs in Indonesia has only reached $1.65 \%$ of the total population. This rate is still very low if it is compared to Malaysia, Thailand and Singapore which is more than $4 \%$. In terms of the health of the entrepreneurial ecosystem, based on 2014 Global Entrepreneurship \& Development Index, Indonesia ranked 68th out of 121 countries. Compared to the G20 countries, The 2013 EY G20 Entrepreneurship Barometer places Indonesia in the fourth quartile, it is the lowest ranking country group in the entrepreneurial ecosystem. This shows that in Indonesia, entrepreneurship has not played an optimal role in supporting the country's economy. Even though entrepreneurship can be a strategic way to overcome the problem of unemployment and poverty in Indonesia. According to David Mc.Celland, a country is advanced if it has entrepreneurs at least $2 \%$ of the total population (Sumarsono, 2015)[2]

Entrepreneurship can be engaged in various fields, such as culinary fields, services, buying and selling, agribusiness and so on, which can be run offline or online. In reality entrepreneurship is highly developed in online business, because only a little capital is needed to make an online business and the process in running online business is not complicated. Tekinfom (www.tekinfom.com), a consulting firm and website maker, even claims that currently there are hundreds of millions of registered and commercialized websites operating in cyberspace. Beginners become internet literate and are accustomed to transacting electronically, online businesses run easily through several media such as websites, facebook, twitter, instagram, path, blog and so on, they will always promise profits for online businesses.

Among students, this online business has become a great opportunity for entrepreneurship. Compared to conventional offline businesses, online businesses have several advantages, including: Online businesses do not need a stall in the form of a kiosk room, they do not need a lot of capital, sales can use social networking by using enough internet access, avoid losses. New sellers bring the goods from the manufacturer if there are interested buyers. The advantages and conveniences of online business are demanded by students in entrepreneurship. 
Decision of running business is the result of interaction of several factors, namely the character of a person's personality and environmental influences (Bygrave dalam Noviantoro, 2017)[3]. A family relationships, friends, relatives, educational environment, social rules in society and religious become an element of the social environment that can influence one's intentions running a business. This is in accordance with the intention of behavior as described in the Theory of Planned Behavior (TPB). This discussion aims to find out how the implications of Theory of Planned Behavior (TPB) in explaining the intention of doing business online among students

\section{Material and Method}

2.1. Online Business Versus Conventional Business According to the Big Indonesian Language Dictionary (KBBI), the meaning of online business is commercial business in trading, both selling products or services, this business uses the internet as its device. The use of the internet in an online business is speeding up the transaction process of various elements in it. One of the most important points in an online business is its ability to connect sellers and buyers effectively and efficiently.

When it is compared to conventional businesses, online businesses have advantages and disadvantages. As Sulianta (2012: 9-10)[4] wrote the advantages of online business as follows:

1. Access online sales time can be 24 hours

2. A very broad business reach even among countries

3. Time efficiency

4. Cheap process, it is able to save resources, especially transportation

5. Increasing privacy, sometimes people are embarrassed to buy a certain product, but with an online business the buyer will not be seen directly

The disadvantages of online business as follows:

1. The existence of goods is difficult to see correctly. Includes color, texture, taste and weight

2. Goods cannot be received immediately after purchase

3. Requiring a series of shopping processes that involve other parties to ensure the successful transaction process (courier service, financial service provider, etc.)

4. The loss of direct human touch

5. Vulnerable to fraud

\subsection{The Intention of Doing Online Business}

Fuadi (2009: 93)[5] states that the intention to conduct business activities is the desire, interest, and willingness to work hard or to be strong-willed to try optimally to fulfill their needs without feeling afraid of the risks that will occur, and willing to learn from failure. The intention of doing online business is the encouragement and desire to try or run an online business.

The following are the intentions to do business as summarized by Iskandar (in Fatonah, 2013)[6], as follows:

1. The Interest in business, indicated by finding various information and knowledge about the business that will be involved

2. Willingness to be involved in business activities, indicated by statements and attitudes of wanting to jump in and engage in business activities

3. Seeing opportunities for business, the interests of individuals doingbusiness because they have seen opportunities to run the chosen business

4. Utilizing the potential possessed for doing business, the potential of themselves and the environment that can be utilized for business success

5. Couraging in dealing with risk, means preparing the courage to deal with it

6. Couraging in facing challenges, means having a high interest in doing business

7. Feeling happy about business activities, indicated by not being depressed when conducting business activities

8. The desire to realize dreams in business

\subsection{Theory of Planned Behavior (TPB)}

Ajzen (1991) in his book The Theory of Planned Behavior, the Organizational Behavior and Human Decision Process, writes that the Theory of Planned Behavior (TPB) postulate states that the central factor of individual behavior is it influenced by behavioral intention towards certain behavior of these. While the intention to behave is influenced by variable attitudes, subjective norms and perceived behavioral control (in Hidayat, 2010)[7]

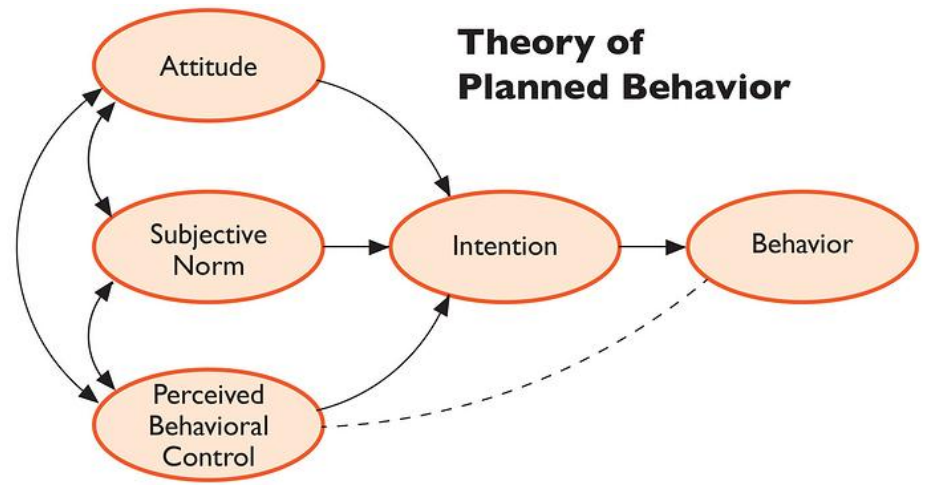

The obstacles and impulses to intention to behave individually can come from internal factors and/ or from external factors

\section{Results and Discussion}

3.1. The Influencing Factors of Online Business Intention among Students

The choice of running business online among students is more desirable than offline (conventional) business among students, it is due to several factors the advantages of online business, including: (1) it does not need for stalls in the form of kiosk rooms, in contrast to conventional stores 
that require stalls; (2) it does not need a lot of capital. Sales can take advantage of social networks, blogs and free chat facilities, just by having internet access; (3) Avoiding the obligation to pay business tax; (4) Avoiding loss, because we have just brought the goods from the producer if there are interested buyers. The advantages and conveniences above make this online business are demanded by students as an option in entrepreneurship.

3.2. Constraints and Solutions of Online Business for Students

M. Irawan Fadli Nasution ST, MM (in Tharob, 2017)[8], in his research was concluded that several obstacles might be occured in an online business and the solution given, as follows:

1. Limited knowledge about online businesses causing online business results is not optimal/ maximum. Solution: increasing knowledge, of course by learning online business from many online business books, taking courses and or training on online business that is currently offered by many online business experts and internet marketing experts.

2. The number of frauds in cyberspace makes consumers distrust in online business. Solution: convincing consumers by including the full address and contact person so that consumers can contact either through chat, telephone, e-mail or sms. Next, maintaining the quality of the products offered and completing product images with supporting information.

3. The very high online business competition supported by the advancement of information and communication technology has supported most people to market their products through the internet more widely. Solution: offering unique products, so the competition is not too high. Then, supporting online business promotion activities by combining it with offline marketing.

4. Internet connection constraints. Solution: using an internet modem that is currently being produced by communication providers. Selecting the modem of which signal is good, so that the internet connection is not hampered.A common problem commonly experienced is when an online shop reseller or businessman has difficulty to find the right supplier partner so that sales activities are hampered because the goods are not available. Solution: Acting professionally, because anyone who wants to be successful must act professionally. making a cooperation agreement, then trying to discuss the contents of the agreement carefully and fairly, so that there is no misunderstanding.

3.3. TPB Implications on Students' Online Business
Intention

The application of the theories related to behavioral intentions which is suitable to be applied in analyzing the intention of running online business among students is the Theory of Planned Behavior. Through this theory, it can be explained that the intention of running online business among students is influenced by some variables such as attitudes, subjective norms, and perceived behavioral control. Furthermore, these three variables are influenced by several backgrounds influencing it, such as social, personal / individual background, and information.

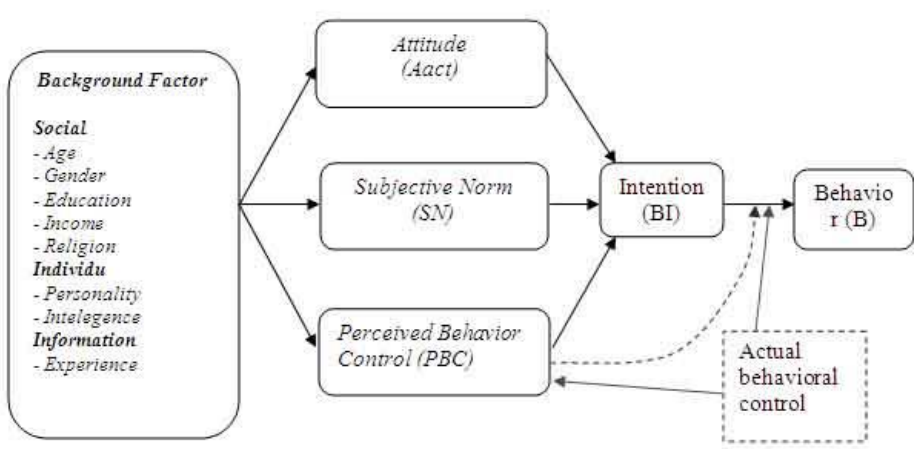

The background factor shows that the intention of running business online for each student can vary depending on their social environment, age, gender, level of education, science, income level, belief / religion, or the influence of exposure of information which affects their experience, besides the influence of students' personality and intellectuality. This is in accordance with the results of research conducted by Sumarsono (2013)[2], Ponco (2017)[9], Ghassani (2015)[10], Izzati (2015)[11], Wahyu (2018)[12], Chairy (2016)[13], Nursito (2013)[14], Tharob (2017)[8], and Wijaya (2015)[15]

\section{Conclusions:}

1. Among students, the choice of running online business is more desirable than running offline business (conventional), it is due to the advantages of online business

2. Some obstacles may arise in doing business online but there is a solution to minimize these obstacles

3. Theory of Planned Behavior can explain that the intention of running online business among students is influenced by some variables such as attitude , individual norms (subjective norm), and behavioral control (perceived behavioral control). Furthermore, these three variables are influenced by several backgrounds influencing it, such as social, personal/ individual background, and information. Several studies have proved the relationship among these variables.

\section{Referensi :}

[1] N. Amir, "Faktor-faktor yang mempengaruhi intensi 
berwirausaha pada mahasiswa program studi manajemen stiem bongaya," Organ. dan Manaj., vol. 1, no. September, 2017.

[2] H. Sumarsono, "Faktor-Faktor Yang Mempengaruhi Intensi Wirausaha Mahasiswa Universitas Muhammadiyah Ponorogo," Ekuilibrium, vol. 11, no. 2 , pp. $62-88,2013$.

[3] G. Noviantoro, "Pengaruh Pengetahuan Kewirausahaan, Motivasi Berwirausaha dan Lingkungan Keluarga Terhadap Minat Berwirausaha pada Mahasiswa Akuntansi Fakultas Ekonomi Universitas Negeri Yogyakarta," eprint.uny.ac.id, 2017.

[4] F. Sulianta, sulianta cover buku.pdf. Penerbit Andy, 2012.

[5] I. F. Fuadi, "Prestasi Praktik Kerja Industri Siswa Kelas XII Teknik Otomotif SMKN I Adiwerna Kabupaten Tegal," PTM, vol. 9, no. 2, 2009.

[6] N. A. Fathonah, "Pengaruh Pembelajaran Kewirausahaan Terhadap Minat Berwirausaha Siswa Kelas XI Pada Jurusan Akuntansi Di SMK Negeri 1 Bandung Tahun Ajaran 2012/2013 Universitas Pendidikan Indonesia | repository.upi.edu | perpustakaan.upi.edu," repository.upi.edu, pp. 2012-2013, 2013.

[7] W. Hidayat, "Studi Empiris Theory of Planned Behavior dan Pengaruh Kewajiban Moral pada Perilaku Ketidakpatuhan Pajak Wajib Pajak Orang Pribadi," Akunt. dan Keuang., vol. 2, no. 12, pp. 82 93, 2003.

[8] G. F. Tharob, E. Mingkid, and R. Paputungan, "Analisis Hambatan Bisnis Online Bagi Mahasiswa Unsrat," Acta Diurna, vol. 6, no. 2, 2017.

[9] R. K. Ponco Dewi and A. Wibowo, "Hubungan Pola Asuh, Kurikulum Kewirausahaan dan Intensi Berwirausaha Mahasiswa Fakultas Ekonomi Universitas Negeri Jakarta," J. Pendidik. Ekon. dan Bisnis, vol. 5, no. 1, pp. 1-17, 2017.

[10] P. F. Ghassani and I. Nurnida, "Mengukur Pengaruh Karakteristik Kewirausahaan terhadap Minat Berwirausaha Mahasiswa Administrasi Bisnis Telkom University Angkatan 2012 1," e-Proceeding Manag., 2015.

[11] N. Izzati, "Motif Penggunaan Gadget Sebagai Sarana Promosi Bisnis Online di Kalangan Mahasiswa UIN Sunan Kalijaga," J. ASPIKOM, 2015.

[12] L. Wahyu Permatasari, S. Kantun, and J. Widodo, "Motivasi Berbisnis Online Secara Reseller pada Mahasiswa Program Studi Pendidikan Ekonomi Fakultas Keguruan dan Ilmu Pendidikan Universitas Jember," J. Pendidik. Ekon. J. Ilm. Ilmu Pendidikan, Ilmu Ekon. dan Ilmu Sos., vol. 12, no. 1, pp. 59-70, 2018.

[13] Chairy, "Pengaruh Karakteristik Entrepreneurial,
Jenis Etnis, Jenis Kelamin Dan Profesi Orang Tua Terhadap Intensi Berwirausaha Mahasiswa," $J$. Manaj. dan Bisnis, 2011.

[14] S. Nursito and A. J. S. Nugroho, "Analisis Pengaruh Interaksi Pengetahuan Kewirausahaan dan Efikasi Diri Terhadap Intensi Wirausaha," Kiat Bisnis, 2013.

[15] T. Wijaya, N. Nurhadi, and A. M. Kuncoro, "Intensi berwirausaha mahasiswa: Perspektif pengambilan risiko," J. Siasat Bisnis, 2015. 